\title{
ARAȘTIRMA RESEARCH
}

\section{Beliren Yetişkinlikte İlişki İstikrarı: Anneye Bağlanma ve Bilişsel Tamamlanma İhtiyacının Yordayıcılığı Relationship Stability in Emerging Adulthood: The Predictions of Maternal Bonding and Need for Cognitive Closure}

\author{
Ahmet Kayabaş 1 id, Hasan Atak ${ }^{1}$ id
}

\section{öz}

Bu çalışmanın temel amacı, anneye bağlanma ve bilişsel tamamlanma ihtiyacının ilişki istikrarı üzerindeki yordayıcı etkisini bir model bağlamında incelemektir. Ek olarak, ilişki istikrarı ve alt ölçeklerinin bazı demografik değişkenlere göre farklılaşıp farkıllaşmadığı incelenmiştir. İlişkisel tarama modelinin kullanıldığı çalışmada araştııma grubunu, 180'i erkek (\%45), 223’ü (\%55) kadın olmak üzere toplam 403 birey oluşturmaktadır. Araştırmada veri toplama aracı olarak "ilişki İstikrarı Ölçeği", "Ebeveyn Bağlanma Envanteri-Anne Kısa Formu" ve "Tamamlanma İhtiyacı Ölçeği-Kısa Formu" kullanıımışır. Path modeli ve t-testi verilerin analizinde yararlanılan temel istatistiklerdir. Araştırma sonucunda, anneye bağlanmanın $(\beta=.16, p<.01)$, bilişsel tamamlanma intiyacının $(B=.21, p<.01)$ ilişki istikrarı üzerinde pozitif ve düşük düzeyde yordayıc gücünün olduğu ortaya çıkmışır. Anneye bağlanmanın $(\beta=.05, p<.01)$ tamamlanma intiyacı üzerinde pozitif ve düşük düzeyde yordayıcı gücünün olduğu ortaya çıkmıştır. Yapılan analiz sonucunda, tamamlanma ihtiyacının aracılık rolü gözlenmektedir. Anneye bağlanmanın $(\beta=.001, p<.01)$ tamamlanma ihtiyacı üzerinden ilişki istikrarına dolaylı etkisinin düşük ve pozitif olduğu bulgusu elde edilmiştir. Anneye bağlanmanın $(\beta=.17, p<.01)$ toplam etkisi ilişki istikrarı ile düşük düzeyde pozitif bulunmuştur.

Anahtar sözcükler: Ilişki istikrarı, anneye bağlanma, bilişsel tamamlanma ihtiyacı, beliren yetişkinlik

\section{Abstract}

The main purpose of this study is to examine the predictive effects of maternal bonding and need for cognitive closure on relationship stability in the context of a model. In addition, it was examined whether the relationship stability and its subscales significantly differed according to some demographic variables. In the study in which the relational descriptive model was used, the research group consists of 403 individuals, $45 \%$ male $(n=180)$ and $55 \%(n=223)$ female. "Relationship Stability Scale", "Parental Attachment Inventory-Mother Short Form" and "Need for Completion Scale-Short Form" were used as data collection tools in the study. Path model and t-Test are the basic statistics used in data analysis. As a result of the research, it was found that maternal bonding $(B=.16$, $p<.01)$ and need for cognitive closure $(B=.21, p<.01)$ has positive and low predictive power on relationship stability. It was found that maternal bonding $(B=.05, \mathrm{p}<.01$ ) has a positive and low level of predictive power on the need for closure. As a result of the analysis, the mediation role of the need for closure is observed. It was found that maternal bonding $(B=.001, p<.01)$ has a low and positive indirect effect on relationship stability through the need for closure. The total effect of maternal bonding $(B=.17, p<.01)$ has a lower effect on stability of the relationship.

Keywords: Relationship stability, maternal bonding, need for cognitive closure, emerging adulthood

${ }^{1}$ Kırıkkale Üniversitesi, Kırıkkale

$\triangle$ Ahmet Kayabaş, Kırıkkale Üniversitesi Sosyal Bilimler Enstitüsü, Kırıkkale, Turkey aahmetkayabas@gmail.com | 0000-0001-7488-0395

Geliş tarihi/Received: 12.05 .2021 | Kabul tarihi/Accepted: 25.09.2021 |Çevrimiçi yayın/Published online: 26.12.2021 
SOSYAL yaşamın bir parçası olarak, her insan, gündelik hayatın içinde farklı insanlarla çeşitli etkileşimlerde bulunmaktadır. Thibaut ve Kelley (1959)'e göre herhangi bir kişilerarası ilişkinin özü etkileşimdir. Etkileşim, kişilerin birbirlerinin varlı̆̆ında davranı̧̧ yaydıkları, birbirleri için ürünler yarattıkları ya da birbirleriyle iletişim kurdukları anlamına gelir. İki kişi, tekrarlanan durumlarda etkileşime girdiklerinde bir ilişki kurarlar.

Yakın ilişki, önemli bir süre boyunca devam eden güçlü, sık ve çeşitli karş1lıklı bağımlılıklardan biridir. (Kelley ve ark. 1983). Yaşam boyu değişim ve gelişim içinde olan yakın ilişkiler; anne-baba, çocuk, arkadaşlık ve aşk ilişkilerini içine alır ve bireyin hayatının önemli bir kısmını kapsar (Reis ve ark. 2000). Aşk, kişisel ilişkileri, bu ilişkilerin özel bir parçasını bazen de bireyin bir başkası için hissettiği bir duyguyu ifade etmek için kullanılmaktadır. Aşk, bağlanma, güven, yakınlık, sevgi ve saygı duygularını içeren bir kavramdır (Atak ve Taştan 2012). Aşk, içinde barındırdığ 1 duygular ve karşılıklı bir etkileşimin sonucu olması sebebiyle diğer ilişki türlerinden farklılaşmaktadır.

1950’lerden beri, romantik ilişkiler alanındaki araştırmacılar dikkatlerini öncelikle ilişkiden duyulan memnuniyet ve ilişkinin sürdürülmesi olmak üzere iki geniş alana yöneltmişlerdir (Adams ve Jones 1999). Kişilerarası ilişkileri eşlerin birbirini etkilediği karşılıklı bir bağımlılık süreci olarak adlandıran Thibaut ve Kelley (1959) doyum ve istikrarı, bireyin ilişkiden elde ettiği kazançları, karşılaştırma düzeyi ve seçenekler için karşılaştırma düzeyi adı verilen iki ölçüte göre değerlendirmesinin bir sonucu olarak açıklamışlardır. Birey beklentilerini içeren ortalama bir değer olan karşılaştırma düzeyinden daha yüksek kazançlar sağladığında ilişkisini doyum verici bulmaktadır. Bireyin olası ilişki seçeneklerini düşünerek oluşturduğu bir değer olan seçenekler için karşılaştırma düzeyinden daha yüksek kazançları mevcut ilişkisinde sağladığında, ilişkiyi sürdürmeye devam edeceğini öne sürmüşlerdir. İlişki doyum verici olduğunda ya da başka ilişki seçenekleri çekici olmadığında bağımlılık artar. İlişkinin sürdürülmesi için ön koşul, eşlerin ödüllerinin yine eşlerin davranışlarına bağımlı olması, yani bir karşılıklı bağımlılık koşuludur (Thibaut ve Kelley 1959). Rusbult ve arkadaşları (2006)'a göre artan bağımlılı̆̆ı bir sonucu olarak bağlanım ortaya çıkmaktadır. Alanyazın incelendiğinde, karşılıklı bağımlılık kuramının görüşlerini ve kavramlarını temel alan bazı kuramcıların ilişki istikrarı üzerine çeşitli bağlanım modelleri geliştirdikleri görülmektedir (Goode 1959, Levinger 1965, Hinde 1979, Rusbult 1980, 1983, Johnson 1991). Bağlanım modellerinin en önemlilerinden biri Rusbult (1980, 1983)'un yatırım modelidir. Rusbult (1991) ilişkinin devam edip etmeyeceği ile ilgili kararı etkileyen temel durumun bağlanım olduğunu ifade etmiştir. Rusbult'un görüşüyle uyumlu olarak Fehr (1988) yaptığı araştırmada, çalışmaya katılan bireylerden ilişki bağlanımını en iyi ifade eden kelimeyi belirtmelerini istemiş, bireylerin çoğu bağlanımı en iyi ifade eden kelimenin ilişkiyi sürdürme kararlılığı olduğunu belirtmişlerdir (Büyükşahin 2006). Rusbult'un bağlanım modelinin karşılıklı bağımlılık kavramlarına en önemli katkısı olan yatırım boyutu, bir ilişkiye bağlanan, ilişkinin sona ermesi durumunda değeri düşecek ya da kaybedilecek kaynakları ifade etmektedir. Bu kaynaklar arttıkça bağlanım artmaktadır (Fehr 2003). İlişki bağlanımının, çeşitli boyutların etkileşimiyle şekillenen bir yapıda olduğu görülmektedir. Bu boyutlar geçmiş yaşantılardan, gözlemlenen ilişkilerden ve değerli olduğu düşünülen kaynakların ilişkiye aktarılması gibi bir dizi durumdan etkilenmektedir (Agnew 2009).

Yakın ilişkilerin ilki bebek ve anne arasında gelişmektedir. Anne, bakıma muhtaç olan bebeğiyle ilgilenmekte, onun fiziksel ihtiyaçlarını gidermektedir. Bu ilk ihtiyaçlar 
bakım, beslenme, uyku, sevgi ve ilgidir (Avc1 2003). Bebek bu dönemde kendisine bakacak olan yetişkine tam anlamıyla bağımlıdır. (Baran ve Aral 2011). Bebeğin annesiyle olan ilişkisini belirtmek amacıyla bağımlılık ve bağlanma kavramları kullanılmaktadır (Ainsworth 1969). Bowbly (1973) bağlanmayı (attachment) bireyin kendisi için önemli olarak nitelediği kişilere karşı geliştirdiğgi, duygusal yönden güçlü bir bağ olarak tanımlamaktadır (Akt. Atak 2010). Bu ilk bağımlı ilişki özel bir ilişki olmakla beraber anne ya da anne yerine geçen kimseye bağımlılık, sonraki kişilerarası ilişkilerin belirleyicisi olarak görülmüştür.

Kruglanski ve Webster (1996)'e göre tamamlanma ihtiyacı insanların sosyal çevreleri için geliştirdikleri yanıtlara etki eden bilişsel bir süreç olarak görülmektedir. Belirli bir durumla ilgili olarak belirsizlik ve karmaşa yerine açı bir bilgiye ulaşma ihtiyacı, karar verme arzusu olarak tanımlanmaktadır (Mayseless ve Kruglanski 1987, Webster ve Kruglanski 1994, 1998, Mannetti ve ark. 2002). Tamamlanma ihtiyacı yüksek bireyler, belirsiz ve düzensiz durumlardan uzak dururlar ve düzenli bir hayatı tercih ederler. Bu bireylerin bir diğer özelliği de öngörülebilirliği yüksek, her koşulda güvenilir olan, beklentilerden etkilenmeyen sağlam ve istikrarlı bilgiyi tercih etmeleridir. Tamamlanma ihtiyacı yüksek olan bireyler kararlı olmaya duydukları ihtiyaçtan dolayı karar vermeye çok çabuk erişmeyi istemektedirler. Aynı zamanda tamamlanmanın mümkün olmadığ1 durumları sevimsiz olarak nitelerler ve belirsizlikten rahatsızlık duyarlar (Atak ve ark. 2016). Bu bağlamda bilişsel tamamlanma ihtiyacının da ilişkinin kalıcılığı ve doyumunun incelenmesine katkı sağlayacağı düşünülebilir.

Beliren yetişkinlik dönemi, sanayileşmiş toplumlarda 18-29 yaş arası bireyler için değişim ve keşiflerin yaygın olduğu, birçok farklı potansiyel geleceğin mümkün olduğu, yaşam olanaklarını araştırarak aşk, iş ve dünya görüşünde daha kalıcı seçimlere ulaştıkları kişisel özgürlük ve keşiflerin diğer zamanlardan yüksek olduğu bir dönemdir (Arnett 2000). Beliren yetişkinlerde romantik ilişkiler yaşamak kimlik keşfine giden süreçte bir gelişim görevidir (Eryılmaz ve Ercan 2010). Gomez ve ark. (2019)'na göre, beliren yetişkinlik, romantik ilişkilerin gelişimde anahtar rol oynadığı ve hem iyi oluşun hem de olumsuz sonuçların kaynağı olabilecek bir aşamadır. Birçok seçimin temellerinin atıldığı bir dönem olan beliren yetişkinlik döneminin, kalıcı seçimlerden biri olması arzu edilen romantik ilişkilerin sağlıklı temeller üzerine inşa edilmesi için kritik bir öneme sahip olduğu söylenebilir.

Alanyazın incelendiğinde anneye bağlanma ve bilişsel tamamlanma ihtiyacının, ilişki istikrarı üzerinde anlamlı bir etkiye sahip olup olmadığını araştıran bir çalışmaya rastlanmamıştır. Ayrıca Türkiye'de yapılan çalı̧̧malar incelendiğinde, bilişsel tamamlanma ihtiyacıyla ilgili az sayıda çalı̧̧ma olduğu görülmektedir. Bu bağlamda, anneye bağlanma, bilişsel tamamlanma ihtiyacı ve ilişki istikrarının beliren yetişkinlik dönemindeki bireyler üzerinde incelenmesi, bu üç kavramın ilişkisinin yönü ve gücü hakkında bilgi vermesinin yanında, anneye bağlanma, bilişsel tamamlanma ihtiyacı ve ilişki istikrarı çalışmalarına da katkı sağlayabilir.

$\mathrm{Bu}$ araştırmanın temel amacı, anneye bağlanma ve bilişsel tamamlanma ihtiyacının, ilişki istikrarını yordayıp yordamadığını incelemektir. Araştırmanın bir diğer amacı ise ilişki istikrarının ve ilişki istikrarının alt boyutları olan ilişki doyumu, seçeneklerin niteliğinin değerlendirilmesi, yatırım ve bağlanımın; cinsiyet, ilişki niteliği, geçmiş ilişki sayısı, yaş ve yetişkinliğe ulaşma algısına göre farklılaşıp farklılaşmadığını incelemektir. $\mathrm{Bu}$ amaçlar doğrultusunda: "Katılımcıların ilişki istikrarı düzeyleri cinsiyete, yaşa, ilişkinin niteliğine, geçmiş ilişki sayısına ve yetişkinliğe ulaşma algısına göre anlamlı 
biçimde farklılaşmakta mıdır?”, "Katılımcıların ilişki doyumu, seçeneklerin niteliğinin değerlendirilmesi, ilişki yatırımı ve ilişki bağlanımı düzeyleri; cinsiyete, yaşa, ilişkinin niteliğine, geçmiş ilişki sayısına ve yetişkinliğe ulaşma algısına göre anlamlı biçimde farklılaşmakta mıdır?", "Katılımcıların anneye bağlanma düzeyleri ilişki istikrarını yordamakta mıdır?”, "Katılımcıların bilişsel tamamlanma ihtiyacı düzeyleri ilişki istikrarını yordamakta mıdır?", "Katılımcıların anneye bağlanma düzeyleri bilişsel tamamlanma ihtiyaçlarını yordamakta mıdır?”, "Anneye bağlanma ve ilişki istikrarı ilişkisinde bilişsel tamamlanma ihtiyacının aracılık etkisi var mıdır?” sorularına yanıt aranacaktır.

\section{Yöntem}

$\mathrm{Bu}$ betimsel araştırmada, farklı yaşlarda bireylerden elde edilen veriler ve kesitsel araştırma deseni kullanılmıştır. Türkiye'deki 18-29 yaş arası beliren yetişkinlik dönemindeki bireylerin anneye bağlanma ve bilişsel tamamlanma ihtiyacı düzeylerinin ilişki istikrarıyla ilişkisinin incelenmesi amacıyla ilişkisel tarama modeli kullanılmı̧̧tır.

\section{Örneklem}

$\mathrm{Bu}$ araştırma, amaçlı örnekleme çeşitlerinden maksimum çeşitlilik yöntemiyle belirlenen çevrimiçi ortam yoluyla ulaşılan Türkiye'deki 18-29 yaş arası beliren yetişkinlik döneminde ve en az bir romantik ilişki yaşamış 403 katılımcıdan oluşmaktadır. Örneklem sayısı belirlenirken G Power programına parametreler girilmiştir. Programın önerdiği kişi sayısı kadar katılımcıdan veri toplanmıştır. Ayrıca ölçme kuralı gereği madde sayısının 10 katı kadar kişiden veri toplanmıştır. Ölçme araçlarının uygulanacağı bireyler, "18-29 yaş arası beliren yetişkinlik dönemindeki bireyler olmak" katılım ölçütü dikkate alınarak belirlenmiştir. Araştırmaya katılan bireylerin çeşitli değişkenlere göre dağılımları Tablo 1'de açıklamalarla sunulmuştur.

\section{İşlem}

Aşağıdaki ölçekler, çevrimiçi ortam yoluyla Türkiye'nin tamamında 18-29 yaş aralığındaki toplam 403 katılımcıya gönüllülük ilkesi esas alınarak ve bireysel olarak uygulanmıştır. Katılımcılara araştırmanın amacıyla ilgili kısa bir bilgi verilmiş, gönüllü olanlara 15-20 dakika süren ölçekler uygulanmıştır. Veriler, Kırıkkale Üniversitesi Sosyal ve Beşerî Bilimler Araştırmaları Etik Kurulu'nun 18.03.2021 tarih ve 3 sayılı izniyle toplanmıştır. Katılımcılardan gönüllülük ilkesine uygun biçimde veri toplanmıştır, katılımcı onamı alınmıştır.

Verilerin toplanması için katılımcılara, Google Formlar üzerinde hazırlanan Kişisel Bilgi Formu, İlişki İstikrarı Ölçeği, Ebeveyn Bağlanma Envanteri-Anne Kısa Formu ve Tamamlanma İhtiyacı Ölçeği-Kısa Formundan oluşan ölçekler internet üzerinden uygulanmıştır. Ölçekler Nisan 2021-Mayıs 2021 tarihleri arasında çevrimiçi ortam yoluyla Türkiye'nin tamamında 18-29 yaş aralığındaki toplam 403 katılımcıya bireysel olarak uygulanmıştır. Katılımcılara; sosyal medya araçları üzerinden yapılan duyurularla ulaşılmış, hiçbir ücret ödenmemiştir. Bireylere ölçekler uygulanmadan önce, yapılan araştırmanın amacı, kişisel bilgilerinin istenmeyeceği, araştırmaya dahil olmalarının gönüllülük esasına dayandığı ve verilen cevapların gizli tutulacağı bilgilendirmesi yapılmıştır. Katılımcılardan kimlik bilgileri istenmemiştir. Katılımcılara araştırma ile ilgili ön bilgi ve ölçeklerin uygulanmasına ilişkin açıklamalar yazılı olarak bildirilmiştir. 
Maddelerin eksiksiz doldurulması için Google Formlar üzerinde gerekli ayarlamalar yapılmıştır. Ölçeklerin katılımcılar tarafından cevaplandırılması ortalama 15-20 dakika sürmüştür.

\section{Veri toplama araçları}

\section{İlişki İstikrarı Ölçeği}

İlişki istikrarını ölçmek için 37 maddeden ve dört alt faktörden (ilişki doyumu, seçeneklerin niteliğini değerlendirme, ilişki yatırımı ve bağlanım) oluşan Rusbult ve arkadaşları (1998) tarafından geliştirilen Büyükşahin ve arkadaşları (2005) tarafından Türkçeye uyarlanan İlişki İstikrarı Ölçeği (İIÖ) kullanılmıştır. İlgili boyutlardan alınan puanların artması boyutun arttığı anlamını taşımaktadır (Büyükşahin 2006). Ölçeğinin ölçüt geçerliğini sınamak amacıyla, İIÖ alt ölçekleri ile Aşka İlişkin Tutumlar Ölçeği: Kısa Formu (LAS) alt ölçekleri arasında bulunan ilişkiler incelenmiş, beklenen yönde ve anlamlı biçimde .48 ile .67 arasında değişen değerler aldıkları sonucuna ulaşılmıştır. Ölçeğin, Cronbach alfa iç tutarlılık katsayısı ilişki doyumu için .90, seçeneklerin niteliğini değerlendirme için .84 ve ilişki yatırımı için .84 olarak hesaplanmıştır. Alt ölçeklerin, iki yarım güvenirlik katsayıları hesaplanmış, sırasıyla $.84, .71$ ve .78 olduğu sonucuna ulaşılmıştır (Büyükşahin 2006). Bu çalışmada Cronbach alfa değeri .78 olarak bulunmuştur.

\section{Ebeveyn Bağlanma Envanteri-Anne Kısa Formu}

Anneye bağlanmayı ölçmek için 12 maddeden ve üç faktörden (güven, iletişim ve yabancılaşma) oluşan, Armsden ve Greenberg (1987) tarafından geliştirilen, Raja ve arkadaşları (1992) tarafından kısa formu hazırlanan ve Günaydın ve arkadaşları (2005) tarafından Türkçeye uyarlanan Ebeveyn Bağlanma Envanteri-Anne Kısa Formu kullanılmıştır. Anneye karşı geliştirilen olumlu bağlanma arttıkça ölçekten yüksek puan alınmaktadır. Güvenirlik çalışması sonucunda iç tutarlılık için hesaplanan Cronbach alfa katsayısı anne formu için .88 baba formu için de .90 olarak tespit edilmiştir (Günaydın ve ark. 2005). Bu çalışmada anne formu için Cronbach alfa değeri .89 olarak bulunmuştur.

\section{Tamamlanma İhtiyacı Ölçeği-Kısa Formu}

Tamamlanma ihtiyacını ölçmek için Roets ve Van Hiel (2011) geliştirilen, Atak ve arkadaşları (2016) tarafından Türkçeye uyarlanan Tamamlanma İhtiyacı Ölçeği-Kısa Formu (TİÖ-KF; Need for Closure Scale (NFC-SV) kullanılmıştır. Ölçek 15 maddeden ve tek boyuttan oluşmaktadır. Ölçekten alınan puanın yükselmesi bilişsel tamamlanma ihtiyacı düzeyinin de yüksek olduğu anlamını taşımaktadır. Atak ve arkadaşları (2016) tarafından yapılan faktör analizi sonucunda, ölçeğin toplam varyansın \%36,7'sini açıkladığı sonucuna ulaşılmıştır. 15 maddeden elde edilen doğrulayıcı faktör analizi sonuçlarına göre ölçeğin faktör yapısı doğrulanmıştır. Ölçeğin iç tutarlılığı için hesaplanan Cronbach alfa değeri .88 olarak bulunmuştur. Ölçeğin güvenirlik çalışmasında iç tutarlılık için hesaplanan Cronbach alfa katsayısı .74 olarak bulunmuştur. Bu bulgu ölçeğin iç tutarlılı̆̆ının kabul edilebilir değerlerde olduğu anlamını taşımaktadır. TİÖ-KF'nin yüksek düzeyde test-tekrar-test güvenirliği gösterdiği $(r=.92)$ sonucuna ulaşılmıştır (Atak ve ark. 2016). $\mathrm{Bu}$ çalışmada Cronbach alfa değeri .87 olarak bulunmuştur. 


\section{İstatistiksel analiz}

Katılımcıların demografik özelliklerinin analizinde frekans ve yüzde analizi; ilişki istikrarı-anneye bağlanma-bilişsel tamamlanma ihtiyacı modelini test etmek için path modeli analizi kullanılmıştır. Path analizi yapılırken araştırmacı mevcut literatür bilgilerini dikkate alarak modeli kurgulamıştır. Değişkenler hem kuramsal bilgiler hem de görgül çalışmalar dikkate alınarak seçilmiştir. Bütün değişkenler için betimsel istatistikler hesaplanmıştır. Verilerin analizi SPSS 25.0 ve LISREL paket programları kullanılarak yapılmıştır. Verilerin demografik özelliklere göre farklılaşıp farklılaşmadığını test etmede ilişkisiz örneklemler için t-testi uygulanmıştır. Veriler analiz edilirken güven aralığ $\% 95$ olarak alınmıştır.

\section{Tablo 1. Araştırma grubunun demografik değişkenlere göre dağılımı}

\begin{tabular}{llll}
\hline Değişken & & N & $\%$ \\
\hline Cinsiyet & Erkek & 180 & 44,7 \\
\hline Yaş & Kadın & 223 & 55,3 \\
\hline & $18-25$ & 187 & 46,4 \\
\hline Yetişkinliğe Ulaşma Algısı & $26-29$ & 216 & 53,6 \\
\hline & Evet & 185 & 45,9 \\
& Bazı Yönlerden Evet Bazı Yönlerden & 218 & 54,1 \\
\hline İlişkinin Niteliği & Hayır & & \\
\hline & Romantik Ilişki (Sevgili İlişkisi) & 218 & 54,1 \\
\hline Geçmiş İlişki Sayısı & Evli & 185 & 45,9 \\
\hline & 1 & 83 & 20,6 \\
\hline
\end{tabular}

\section{Bulgular}

Katılımcıların ilişki istikrarı ve alt ölçek düzeylerinin demografik değişkenlere göre anlamlı bir şekilde farklılaşıp farklılaşmadığını test etmek amacıyla bağımsız gruplar için t-Testi kullanılmıştır.

Tablo 2. İlişki istikrarı ve alt ölçeklerinin cinsiyete göre oluşturulan gruplar açısından t-testi sonuçları

\begin{tabular}{|c|c|c|c|c|c|c|c|}
\hline & Cinsiyet & $\mathbf{N}$ & Ort. & SS & sd & $\mathbf{t}$ & $\mathbf{P}$ \\
\hline \multirow{2}{*}{$\begin{array}{l}\text { İlişki } \\
\text { İstikrarı }\end{array}$} & Erkek & 180 & 6.56 & .90 & 401 & 2.74 & .006 \\
\hline & Kadın & 223 & 6.31 & .91 & & & \\
\hline \multirow{2}{*}{$\begin{array}{l}\text { İlişki } \\
\text { Doyumu }\end{array}$} & Erkek & 180 & 7.63 & 1.59 & 401 & .61 & .540 \\
\hline & Kadın & 223 & 7.53 & 1.57 & & & \\
\hline \multirow{2}{*}{$\begin{array}{l}\text { Seçeneklerin Niteliğini } \\
\text { Değerlendirme }\end{array}$} & Erkek & 180 & 4.71 & 2.16 & 401 & 2.45 & .015 \\
\hline & Kadın & 223 & 4.20 & 2.00 & & & \\
\hline \multirow{2}{*}{$\begin{array}{l}\text { İlişki } \\
\text { Yatırımı }\end{array}$} & Erkek & 180 & 5.73 & 1.89 & 401 & 3.65 & .000 \\
\hline & Kadın & 223 & 5.02 & 1.95 & & & \\
\hline \multirow[t]{2}{*}{ Bağlanım } & Erkek & 180 & 7.72 & 1.54 & 401 & -.95 & .344 \\
\hline & Kadın & 223 & 7.87 & 1.62 & & & \\
\hline
\end{tabular}

Tablo 2'de görüldüğü üzere, ilişki istikrarı düzeyinin cinsiyete göre anlamlı bir fark gösterdiği bulunmuştur $(\mathrm{t}(401)=2.74, \mathrm{p}<.05)$. Erkeklerin ortalaması (Ort.= 6.56) 
kadınlara göre $($ Ort.= 6.31) anlamlı olarak daha yüksek bulunmuştur. Diğer verilere bakıldığında; erkek ve kadın katılımcıların seçeneklerin niteliğini değerlendirme ( $\mathrm{t}(401)$ $=2.45, \mathrm{p}<.05)$ ve ilişki yatırımı $(\mathrm{t}(401)=3.65, \mathrm{p}<.05)$ alt ölçeklerinin cinsiyete göre anlamlı bir fark gösterdiğ̣i, seçeneklerin niteliğini değerlendirme düzeylerinde erkeklerin ortalaması (Ort. $=4.71)$ kadınlara göre $($ Ort. $=4.20)$, ilişki yatırımı düzeylerinde erkeklerin ortalaması (Ort. $=5.73)$ kadınlara $($ Ort. $=5.02)$ göre anlamlı bir biçimde daha yüksek bulunmuştur. Yapılan analizde katılımcıların ilişki doyumu $(\mathrm{t}(401)=.61, \mathrm{p}>.05)$ ve bağlanım $(\mathrm{t}(401)=-.95, \mathrm{p}>.05)$ düzeylerinin cinsiyete göre farklılaşmadığ bulunmuştur.

Tablo 3. İlişki istikrarı ve alt ölçeklerinin yaşa göre oluşturulan gruplar açısından t-testi sonuçları

\begin{tabular}{|c|c|c|c|c|c|c|c|}
\hline & Yaş & $\mathbf{N}$ & Ort. & SS & Sd & $\mathbf{T}$ & p \\
\hline \multirow[t]{2}{*}{$\begin{array}{l}\text { İlişki } \\
\text { İstikrarı }\end{array}$} & $18-25$ & 187 & 6.34 & .99 & 401 & -1.80 & .073 \\
\hline & $26-29$ & 216 & 6.50 & .85 & & & \\
\hline \multirow[t]{2}{*}{$\begin{array}{l}\text { İlişki } \\
\text { Doyumu }\end{array}$} & $18-25$ & 187 & 7.46 & 1.62 & 401 & -1.31 & .190 \\
\hline & $26-29$ & 216 & 7.67 & 1.55 & & & \\
\hline \multirow[t]{2}{*}{$\begin{array}{l}\text { Seçeneklerin } \\
\text { Niteliğini Değer- } \\
\text { lendirme }\end{array}$} & $18-25$ & 187 & 4.41 & 2.16 & 401 & -.18 & .854 \\
\hline & $26-29$ & 216 & 4.45 & 2.03 & & & \\
\hline \multirow[t]{2}{*}{$\begin{array}{l}\text { İlişki } \\
\text { Yatırımı }\end{array}$} & $18-25$ & 187 & 5.42 & 2.12 & 401 & .76 & .447 \\
\hline & $26-29$ & 216 & 5.27 & 1.80 & & & \\
\hline \multirow[t]{2}{*}{ Bağlanım } & $18-25$ & 187 & 7.56 & 1.69 & 401 & -2.85 & .005 \\
\hline & $26-29$ & 216 & 8.01 & 1.46 & & & \\
\hline
\end{tabular}

Tablo 4. İlişki istikrarı ve alt ölçeklerinin yetişkinliğe ulaşma algısına göre oluşturulan gruplar açısından t-testi sonuçları

\begin{tabular}{|c|c|c|c|c|c|c|c|}
\hline & Yetişkinliğe Ulaşma Algısı & $\mathbf{N}$ & Ort. & SS & Sd & $\mathbf{T}$ & $\mathbf{p}$ \\
\hline \multirow[t]{2}{*}{ İliş̧ki İstikrarı } & Evet & 185 & 6.44 & .87 & 401 & .34 & .733 \\
\hline & $\begin{array}{l}\text { Bazı Yönlerden Evet Bazı Yönlerden } \\
\text { Hayır }\end{array}$ & 218 & 6.41 & .95 & & & \\
\hline \multirow[t]{2}{*}{ İlişki Doyumu } & Evet & 185 & 7.70 & 1.50 & 401 & 1.44 & .150 \\
\hline & $\begin{array}{l}\text { Bazı Yönlerden Evet Bazı Yönlerden } \\
\text { Hayır }\end{array}$ & 218 & 7.47 & 1.64 & & & \\
\hline \multirow{2}{*}{$\begin{array}{l}\text { Seçeneklerin Niteliğini } \\
\text { Değerlendirme }\end{array}$} & Evet & 185 & 4.16 & 2.08 & 401 & -2.46 & .014 \\
\hline & $\begin{array}{l}\text { Bazı Yönlerden Evet Bazı Yönlerden } \\
\text { Hayır }\end{array}$ & 218 & 4.67 & 2.07 & & & \\
\hline \multirow[t]{2}{*}{ İlişki Yatırımı } & Evet & 185 & 5.40 & 2.05 & 401 & .59 & .554 \\
\hline & $\begin{array}{l}\text { Bazı Yönlerden Evet Bazı Yönlerden } \\
\text { Hayır }\end{array}$ & 218 & 5.28 & 1.87 & & & \\
\hline \multirow[t]{2}{*}{ Bağlanım } & Evet & 185 & 7.92 & 1.51 & 401 & 1.37 & .171 \\
\hline & $\begin{array}{l}\text { Bazı Yönlerden Evet Bazı Yönlerden } \\
\text { Hayır }\end{array}$ & 218 & 7.70 & 1.64 & & & \\
\hline
\end{tabular}

Tablo 3'te görüldüğü üzere, katılımcıların ilişki istikrarı düzeylerinin yaşa göre anlamlı bir fark göstermediği bulunmuştur $(\mathrm{t}(401)=-1.80, \mathrm{p}>.05)$. Alt ölçeklerle ilgili verilere bakıldığında; yaşa göre katılımcıların bağlanım düzeylerinin ( $\mathrm{t}(401)=-2.85$, 
$\mathrm{p}<.05)$ anlamlı bir biçimde farklılaştı̆̆ 1, ilişki doyumu ( $\mathrm{t}(401)=-1.31, \mathrm{p}>.05)$, seçeneklerin niteliğini değerlendirme $(\mathrm{t}(401)=-.18, \mathrm{p}>.05)$ ve ilişki yatırımı $(\mathrm{t}(401)=$ .76, p>.05) düzeylerinin yaşa göre anlamlı bir fark göstermediği bulunmuştur. Katılımcıların yaşa göre bağlanım düzeyleri karşılaştırıldığında 26-29 yaş grubunun ortalaması (Ort.= 8.01) 18-25 yaş grubuna göre (Ort.= 7.56) anlamlı bir şekilde daha yüksek bulunmuştur.

Tablo 4'te görüldüğü üzere, katılımcıların ilişki istikrarı düzeylerinin yetişkinliğe ulaşma algılarına göre anlamlı bir fark göstermediği bulunmuştur $(\mathrm{t}(401)=.34, \mathrm{p}>.05)$. Diğer verilere bakıldığında; yetişkinliğe ulaşma algılarına göre katılımcıların seçeneklerin niteliğini değerlendirme düzeylerinin $(\mathrm{t}(401)=-2.46, \mathrm{p}<.05)$ anlamlı bir biçimde farklılaştığ 1 , ilişki doyumu $(\mathrm{t}(401)=1.44, \mathrm{p}>.05)$, ilişki yatırımı $(\mathrm{t}(401)=.59, \mathrm{p}>.05)$ ve ilişki bağlanımı $(\mathrm{t}(401)=1.37, \mathrm{p}>.05)$ düzeylerinin anlamlı bir fark göstermediği bulunmuştur. Katılımcıların seçeneklerin niteliğini değerlendirme düzeyleri karşılaştırıldığında yetişkinliğe ulaştıklarını düşünenlerin ortalaması (Ort.= 2.08) bazı yönlerden ulaşıp bazı yönlerden ulaşmadıklarını düşünenlere göre (Ort.= 2.07) anlamlı bir biçimde yüksek bulunmuştur.

Tablo 5. İlişki istikrarı ve alt ölçeklerinin geçmiş ilişki sayısına göre oluşturulan gruplar açısından t-testi sonuçları

\begin{tabular}{llcccccc}
\hline & ilişki Sayısı & N & Ort. & SS & Sd & T & P \\
\hline İlişki ístikrarı & 1 & 83 & 6.52 & .86 & 401 & 1.09 & .276 \\
\hline & 2 ve üzeri & 320 & 6.40 & .93 & & & \\
\hline İlişki Doyumu & 1 & 83 & 7.85 & 1.35 & 401 & 1.77 & .077 \\
\hline & 2 ve üzeri & 320 & 7.50 & 1.62 & & & \\
\hline $\begin{array}{l}\text { Seçeneklerin Niteliğini } \\
\text { Değerlendirme }\end{array}$ & 1 & 83 & 3.68 & 2.07 & 401 & -3.74 & .000 \\
\hline & 2 ve üzeri & 320 & 4.63 & 2.05 & & & \\
\hline Ilişki Yatırımı & 1 & 83 & 5.74 & 2.06 & 401 & 2.12 & .035 \\
\hline & 2 ve üzeri & 320 & 5.23 & 1.91 & & & \\
\hline Bağlanım & 1 & 83 & 8.16 & 1.30 & 401 & 2.35 & .019 \\
\hline & 2 ve üzeri & 320 & 7.71 & 1.64 & & & \\
\hline
\end{tabular}

Tablo 5'te görüldüğü üzere, katılımcıların ilişki istikrarı düzeylerinin geçmiş ilişki sayısına göre anlamlı bir fark göstermediği bulunmuştur $(t(401)=1.09$, p>.05). Diğger verilere bakıldığında; geçmiş ilişki sayısına göre katılımcıların seçeneklerin niteliğini değerlendirme $(\mathrm{t}(401)=-2.85, \mathrm{p}<.05)$, ilişki yatırımı $(\mathrm{t}(401)=-2.85, \mathrm{p}<.05)$ ve bağlanım $(\mathrm{t}(401)=-2.85, \mathrm{p}<.05)$ düzeylerinin anlamlı bir biçimde farklılaştığı, ilişki doyumu $(\mathrm{t}(401)=-1.31, \mathrm{p}>.05)$ düzeyinin anlamlı bir fark göstermediği bulunmuştur. Katılımcıların seçeneklerin niteliğinin değerlendirilmesi düzeyleri karşılaştırıldığında 2 ve üzeri ilişki yaşadığını belirten grubun ortalaması (Ort.= 4.63) 1 ilişki yaşadığını belirten gruptan (Ort.= 3.68), ilişki yatırımı düzeyleri karşılaştırıldığında 1 ilişki yaşadığını belirten grubun ortalaması (Ort.= 5.74) 2 ve üzeri ilişki yaşadığını belirten gruptan (Ort.= 5.23), bağlanım düzeyleri karşılaştırıldığında 1 ilişki yaşadığını belirten grubun ortalaması (Ort.= 8.16) 2 ve üzeri ilişki yaşadığını belirten gruptan (Ort.= 7.71) anlamlı bir biçimde yüksek bulunmuştur.

Tablo 6'da görüldüğü üzere, katılımcıların ilişki istikrarı düzeylerinin ilişkinin niteliğine göre anlamlı biçimde farklılaştığı bulunmuştur $(\mathrm{t}(401)=-6.91, \mathrm{p}<.05)$. Evli olduğunu belirten grubun ortalaması (Ort.= 6.75) romantik ilişki yaşadığını belirten gruba göre $($ Ort.= 6.15) anlamlı biçimde yüksek bulunmuştur. Alt ölçeklerle ilgili verilere 
bakıldı̆̆ında; ilişkinin niteliğine göre katılımcıların ilişki doyumu ( $\mathrm{t}(401)=-5.96$, $\mathrm{p}<.05)$, seçeneklerin niteliğini değerlendirme $(\mathrm{t}(401)=5.21, \mathrm{p}<.05)$, ilişki yatırımı $(\mathrm{t}$ $(401)=-6.54, \mathrm{p}<.05)$ ve bağlanım $(\mathrm{t}(401)=-7.57, \mathrm{p}<.05)$ düzeylerinin anlamlı biçimde farklılaştığ bulunmuştur. Katılımcıların ilişki doyumu düzeyleri karşılaştırıldığında evli olduğunu belirten grubun ortalaması (Ort.= 8.06) romantik ilişki yaşadığını belirten gruptan (Ort.= 7.16), seçeneklerin niteliğini değerlendirme düzeyleri karşılaştırıldığında romantik ilişki yaşadığını belirten grubun ortalaması (Ort.= 4.91), evli gruptan (Ort.= 3.86), ilişki yatırımı düzeyleri karşılaştırıldığında evli olan grubun ortalaması (Ort.= 5.99), romantik ilişki yaşayan gruptan (Ort.= 4.78), bağlanım düzeyleri karşılaştırıldığında evli olan grubun ortalaması (Ort.= 8.41), romantik ilişki yaşayan gruptan (Ort.= 7.29) anlamlı biçimde yüksek bulunmuştur.

Tablo 6. Iliş̧ki istikrarı ve alt ölçeklerinin ilişkinin niteliğine göre oluşturulan gruplar açısından t-testi sonuçları

\begin{tabular}{|c|c|c|c|c|c|c|c|}
\hline & İlişkinin Niteliği & $\mathbf{N}$ & Ort. & SS & Sd & $\mathbf{T}$ & $\mathbf{P}$ \\
\hline \multirow[t]{2}{*}{ İlişki İstikrarı } & $\begin{array}{l}\text { Romantik iliş̧ki (Sevgili } \\
\text { İlişkisi) }\end{array}$ & 218 & 6.15 & .97 & 401 & -6.91 & .000 \\
\hline & Evli & 185 & 6.75 & .73 & & & \\
\hline \multirow[t]{2}{*}{ İlişki Doyumu } & $\begin{array}{l}\text { Romantik iliş̧ki (Sevgili } \\
\text { İlişkisi) }\end{array}$ & 218 & 7.16 & 1.68 & 401 & -5.96 & .000 \\
\hline & Evli & 185 & 8.06 & 1.29 & & & \\
\hline \multirow[t]{2}{*}{$\begin{array}{l}\text { Seçeneklerin Niteliğini } \\
\text { Değerlendirme }\end{array}$} & $\begin{array}{l}\text { Romantik iliş̧ki (Sevgili } \\
\text { İlişkisi) }\end{array}$ & 218 & 4.91 & 1.97 & 401 & 5.21 & .000 \\
\hline & Evli & 185 & 3.86 & 2.08 & & & \\
\hline \multirow[t]{2}{*}{ İlişki Yatırımı } & $\begin{array}{l}\text { Romantik Illişki (Sevgili } \\
\text { İlişkisi) }\end{array}$ & 218 & 4.78 & 1.94 & 401 & -6.54 & .000 \\
\hline & Evli & 185 & 5.99 & 1.75 & & & \\
\hline \multirow[t]{2}{*}{ Bağlanım } & $\begin{array}{l}\text { Romantik İlişki (Sevgili } \\
\text { İlişkisi) }\end{array}$ & 218 & 7.29 & 1.70 & 401 & -7.57 & .000 \\
\hline & Evli & 185 & 8.41 & 1.19 & & & \\
\hline
\end{tabular}

Tablo 7. Değişkenler arasındaki korelasyon değerleri

\begin{tabular}{|c|c|c|c|}
\hline Değişkenler & $\begin{array}{c}\text { ílişki } \\
\text { İstikrarı }\end{array}$ & Anneye Bağlanma & Bilişsel Tamamlanma Ihtiyacı \\
\hline illişki İstikrarı & 1 & $.17^{* *}$ & $.21^{* *}$ \\
\hline Anneye Bağlanma & & 1 & .05 \\
\hline Bilişsel Tamamlanma İhtiyacı & & & 1 \\
\hline
\end{tabular}

" $\mathrm{p}<.01, " \mathrm{p}<.05$

Araştırmada, araştırma grubunun ilişki istikrarı, anneye bağlanma ve bilişsel tamamlanma ihtiyacı ortalama puanları arasındaki korelasyon incelenmiş ve sonuçları Tablo 7'de verilmiştir. Korelasyon analizi sonucuna göre, ilişki istikrarı ile anneye bağlanma $(\mathrm{r}=.17 ; \mathrm{p}<.01)$ ve bilişsel tamamlanma ihtiyacı $(\mathrm{r}=.21 ; \mathrm{p}<.01)$ arasında pozitif ve düşük düzeyde anlamlı bir ilişki vardır. Korelasyon analizinin bir diğer sonucuna göre ise anneye bağlanma ve bilişsel tamamlanma ihtiyacı arasında anlamlı bir ilişki bulunmamıştır $(r=.05 ; \mathrm{p}>.05)$. Bu sonuçlara göre bireylerin ilişki istikrarı düzeylerinin anneye bağlanma ile bilişsel tamamlanma ihtiyacını yordadığı ve pozitif ilişkili olduğu görülmüştür. Bu sonuca göre model testi için gerekli korelasyon yeterliliğine ulaşıldığını söylemek mümkündür. Bu işlemden sonra kavramsal modelin test edilmesine geçilmiştir. 
Tablo 7'deki korelasyon analizinden de yararlanılarak kavramsal modelin analizi (standardize katsayılar) yapılmıştır. Sonuçları Şekil 1'de gösterilmiştir.

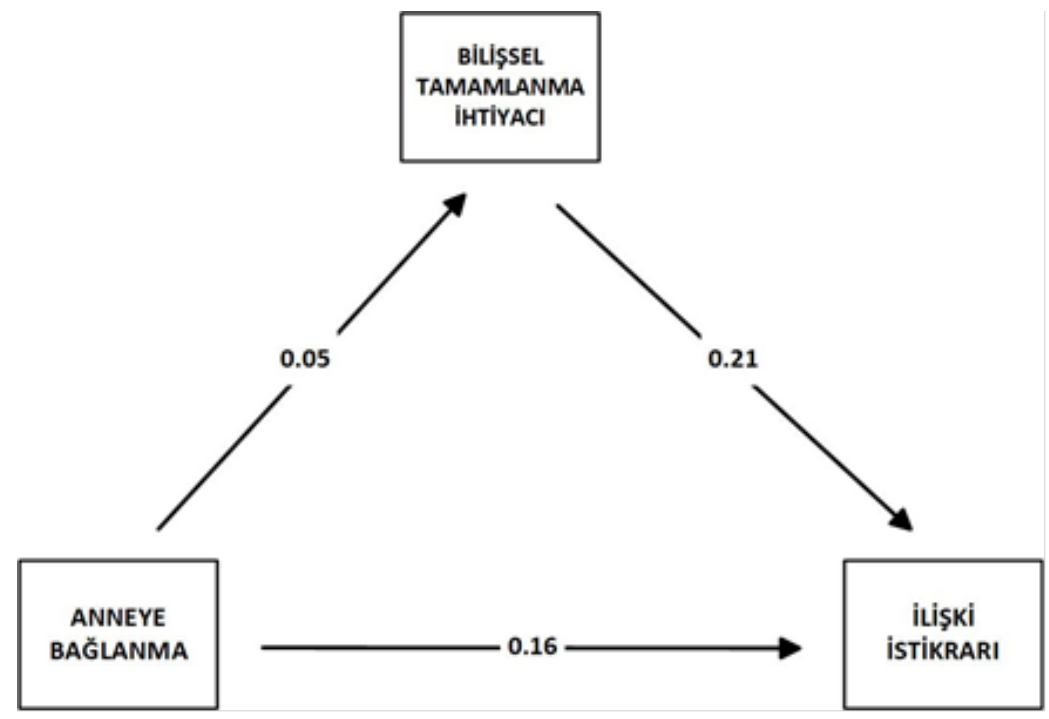

Şekil 1. Model analizi (standardize katsayılar)

Tablo 8. Modelin path analizi sonuçları

\begin{tabular}{lc}
\hline Uyum Indeksleri & Uyum Değerleri \\
\hline Ki-Kare/Serbestlik Derecesi & 0 \\
\hline RMSEA & 0.000 \\
\hline CFI & 1.00 \\
\hline IFI & 1.00 \\
\hline NFI & 1.00 \\
\hline TLI & 1.00 \\
\hline GFI & 1.00 \\
\hline AGFI & 1.00 \\
\hline
\end{tabular}

Analiz sonrası modele ilişkin uyum değerleri Tablo 8.'de verilmiştir. Test edilen modelden elde edilen uyum katsayılarına bakıldığında, $\mathrm{CFI}=1.00, \mathrm{IFI}=1.00, \mathrm{NFI}=1.00$, $\mathrm{TLI}=1.00, \mathrm{GFI}=1.00$ ve $\mathrm{AGFI}=1.00$ olduğu görülmektedir. Ki-Kare/Serbestlik Derecesi $\left(\chi^{2} /\right.$ sd) 0; RMSEA değerleri ise .000 olarak bulunmuştur (Bkz. Tablo 8.). Analiz sonucuna göre Ki-Kare ve RMSEA değerlerinin .05'ten düşük olduğu görülmektedir. Ki-Kare ve RMSEA değerlerinin .05'ten düşük ve CFI, IFI, NFI, TLI uyum değerlerinin .95 'ten yüksek olması test edilen modelin “doymuş model” olduğunu göstermektedir (Şimşek 2007). Bu nedenle iyileştirme indekslerinin incelenmesine ihtiyaç duyulmamıştır.

Tablo 9. Yordayıcı değişkenlerin yordanan değişkenler üzerindeki etki değerleri

\begin{tabular}{lccccc}
\hline & \multicolumn{7}{c}{ Ilişki İstikrarı } & Anneye Bağlanma & Tamamlanma İhtiyacı \\
\hline & $\mathbf{1}$ & $\mathbf{2}$ & $\mathbf{3}$ & $\mathbf{1}$ & $\mathbf{1}$ \\
\hline Anneye Bağlanma & .16 & .011 & .17 & & .05 \\
\hline Tamamlanma İhtiyacı & .21 & & & & \\
\hline 1: Doğrudan Etki; 2: Dolaylı Etki; 3: Toplam Etki & & & &
\end{tabular}


Modelde "doğrudan etkilere" bakıldığında anneye bağlanma ( $ß=.16, p<.01)$, ve tamamlanma ihtiyacı $(B=.21, \mathrm{p}<.01)$ ilişki istikrarı ile pozitif ve düşük ilişkili bulunmuştur. Anneye bağlanma $(\beta=.05, \mathrm{p}<.01)$ bilişsel tamamlanma ihtiyacı ile pozitif ve düşük ilişkili bulunmuştur. Değişkenler arasındaki dolaylı etkileri incelemek, tamamlanma ihtiyacının aracılık rolünün anlaşılmasına katkı sağlayacaktır (Tablo 9).

Hipotez modelde tamamlanma ihtiyacının anneye bağlanma ile ilişki istikrarı arasında aracılık (mediator) rolü tanımlanmıştı. Yapılan analiz sonucunda, tamamlanma ihtiyacının aracılık rolü gözlenmektedir. Başka bir ifadeyle anneye bağlanma tamamlanma ihtiyacına etki etmekte; bu durum ise ilişki istikrarına etki etmektedir.

Değişkenler arasındaki dolaylı etkiler incelendiğinde, anneye bağlanmanın $(ß=.011$, $\mathrm{p}<.01$ ) ve bilişsel tamamlanma ihtiyacı üzerinden ilişki istikrarına dolaylı etkisinin düşük ve pozitif olduğu görülmektedir. Genel olarak bulgulara bakıldı̆̆ında, modelde tamamlanma ihtiyacinın aracılık rolünün olduğu görülmektedir ve bu bulgu "tamamlanma ihtiyacının anneye bağlanma ile ilişki istikrarı arasında aracı rolü vardır" hipotezini doğrulamıştır (Tablo 9).

"Toplam etki", bir değişkenle bir başka değişken arasında bulunan bütün doğrudan ve dolaylı etkilerin toplamını ifade etmektedir. Toplam etkiler incelendiğinde, anneye bağlanmanın $(ß=.17, \mathrm{p}<.01)$ toplam etkisi ilişki istikrarı ile düşük düzeyde pozitif ilişkili bulunmuştur. Genel olarak, anneye bağlanmanın ilişki istikrarı üzerindeki toplam etkisinin anlamlı olduğu ifade edilebilir.

Model genel olarak incelendiğinde hem anneye bağlanmanın hem de tamamlanma ihtiyacının ilişki istikrarı üzerindeki etkisinin anlamlı olduğu, anneye bağlanmanın tamamlanma ihtiyacı üzerinden ilişki istikrarına olan etkisinin de anlamlı olduğu ifade edilebilir. Daha ayrıntılı olarak ise, anneye bağlanma ve tamamlanma ihtiyacının ilişki istikrarı üzerinde pozitif etkisinin olduğu söylenebilir.

\section{Tartışma}

Genel olarak bulgulara bakıldığında, ilişki istikrarının cinsiyet ve ilişkinin niteliğine göre anlamlı bir biçimde farklılaştığı; yaş, yetişkinliğe ulaşma algısı ve ilişki sayısına göre anlamlı bir farklılık olmadığ 1 bulunmuştur. İlişki istikrarı alt boyutlarından olan ilişki doyumunun ilişkinin niteliğine göre anlamlı bir biçimde farklılaştığı; cinsiyet, yaş, yetişkinliğe ulaşma algısı ve geçmiş ilişki sayısına göre anlamlı bir farklılaşma olmadığı bulunmuştur. Seçeneklerin niteliğinin değerlendirilmesi alt boyutunun ise cinsiyet, yetişkinliğe ulaşma algısı, ilişki sayısı ve ilişkinin niteliğine göre anlamlı bir biçimde farklılaştığı, yaşa göre anlamlı bir farklılık olmadığı sonucuna ulaşılmıştır. İlişki yatırımı alt boyutunun ise cinsiyet ilişki sayısı ve ilişkinin niteliğine göre anlamlı bir biçimde farklılaştığı, yaş ve yetişkinliğe ulaşma algısına göre anlamlı bir farklılık bulunmadığ 1 görülmüştür. İlişki istikrarı ölçeğine sonradan eklenen ve son alt boyut olan bağlanımın, yaş ilişki sayısı ve ilişkinin niteliğine göre anlamlı bir biçimde farklılaştığı, cinsiyet ve yetişkinliğe ulaşma algısına göre anlamlı bir farklılık bulunmadığı sonucuna ulaşılmıştır. Anneye bağlanma ve bilişsel tamamlanma ihtiyacı, ilişki istikrarı ile düşük düzeyde pozitif ilişkili bulunmuştur. Anneye bağlanma ve bilişsel tamamlanma ihtiyacı arasında pozitif ve düşük düzeyde ilişki bulunmuştur.

Alanyazın incelendiğinde ilişki istikrarı toplam puanı ve demografik değişkenlerin birlikte değerlendirildiği az sayıda çalışma olduğu görülmektedir. Çelik- Zeren (2020) araştırmasında cinsiyetin ilişki istikrarı üzerinde anlamlı bir etkisinin bulunduğu, 
erkeklerin ortalamasının, kadınlardan yüksek olduğu sonucuna ulaşmıştır. Bu çalışma araştırmamızın bulgusuyla tutarlıdır. İlişki istikrarında erkeklerin ortalamasının anlamlı biçimde farklılaşmasında kültürel olarak cinsiyete göre belirlenen toplumsal rollerin etkili olduğu söylenebilir. İlişkinin niteliği değişkeninin de ilişki istikrarı üzerinde anlamlı bir etkisinin bulunduğu evli katılımcıların romantik ilişkisi bulunanlara göre ilişki istikrarı düzeylerinin yüksek olduğu sonucuna ulaşılmıştır. Bu bulgu evli bireylerin ilişkilerini sürdürmekte kararlı olacakları yönündeki beklentiyi karşılamaktadır. Bu bulgu ÇelikZeren (2020)'in araştırmasındaki bulguyla çelişmektedir. Bunun sebebi evli bireylerin ölçeği partnerleriyle birlikte doldurma ihtimalleri olabilir. Bu çalışmada ilişki istikrarının yaş, yetişkinliğe ulaşma algısı ve geçmiş ilişki sayısına göre anlamlı bir fark göstermediği sonucuna ulaşılmıştır. Alanyazın incelendiğinde bu değişkenlerin ilişkisiyle ilgili herhangi bir bulguya rastlanmamıştır. Bu demografik değişkenlerin incelenmesi açısından alanyazına katkı sağlandığı söylenebilir.

$\mathrm{Bu}$ araştırmada cinsiyetin ilişki doyumu üzerinde anlamlı bir etkisinin bulunmadığı sonucuna ulaş1lmıştır. Bu sonuç Uzun (2017), Şahin (2015), Akarsu (2018), Çaykuş (2020) ve Çelik-Zeren (2020)'in çalışmalarıyla tutarlıdır. Bu çalışmada yaşa göre ilişki doyumu düzeylerinin karşılaştırılması sonucunda yaşın ilişki doyumu üzerinde anlamlı bir etkisinin bulunmadığı sonucuna ulaşılmış, bu bulgunun Şahin (2015), Mamati (2018) ve Çaykuş (2020)'un çalışmalarıyla tutarlı olduğu, Tai ve arkadaşları (2014)'nın ilişki doyumunun genç kadınlarda yüksekken yaş ilerledikçe azaldığı ve Uzun (2017)'un yaş ilerledikçe doyumun azaldığı bulgularıyla çeliştiği görülmüştür. Sosyo-ekonomik ve kültürel çeşitliliklerin alanyazındaki bulguların farklılaşmasına neden olduğu söylenebilir. Yetişkinliğe ulaşma algısının doyum üzerinde anlamlı bir etkisinin bulunmadığı sonucuna ulaşılmıştır. Alanyazın incelendiğinde bu değişkenin daha önce incelenmediği ve bu yönüyle araştırmamızın özgün bulgularından biri olduğu söylenebilir. Bu araştırmada geçmiş ilişki sayısının doyum üzerinde anlamlı bir etkisinin olmadığı bulgusu elde edilmiş, bu bulgunun Şahin (2015)'in araştırmasıyla tutarlı olduğu görülmüştür. İlişkinin niteliğinin ilişki doyumu üzerinde anlamlı bir etkisinin olduğu ve evli katılımcıların ortalamasının, romantik ilişki ya da sevgili ilişkisi yaşadığını belirten katılımcılardan anlamlı bir biçimde yüksek olduğu sonucuna ulaşılmıştır. Bu bulgunun Şahin (2015)'in ve Büyükşahin (2006)'in bulgularıyla tutarlı olduğu görülmüştür. Bunun sebebi Tai ve arkadaşları (2014)'nın araştırmasındaki gibi evlenme niyeti olanların evlenme niyeti olmayanlara göre ilişkiden daha fazla doyum almaları olabilir. Geleceğe yönelik plan yapma düzeyi arttıkça ilişki doyumu artmaktadır (Büyükşahin 2006).

$\mathrm{Bu}$ çalışmada cinsiyetin seçeneklerin niteliğini değerlendirme düzeyine anlamlı bir etkisinin olduğu ve erkeklerin kadınlara göre daha yüksek puanlar aldıkları sonucuna ulaşılmıştır. Alanyazın incelendiğinde bu araştırmanın bulgularıyla tutarlı çalışmalar (Sacher ve Fine 1996, Rusbult ve ark. 1998, Fitzpatrick ve Sollie 1999, Büyükşahin 2006, Halat 2009, Buğa 2009, Akarsu 2018, Çaykuş 2020, Çelik-Zeren 2020) olduğu gibi çelişen çalışmalar (Le ve Agnew 2003, Şahin 2015, Uzun, 2017, Aktaş-Akbayrak 2019) bulunduğu da görülmüştür. Araştırmamızda elde edilen bulgunun kültürel olarak erkeklere ve kadınlara atfedilen rollerdeki farklılıklardan kaynaklandığı düşünülebilir. Araştırmamızda elde edilen yaşın seçeneklerin niteliğinin değerlendirme düzeyi üzerinde anlamlı bir etkisinin bulunmadığı sonucu Mamati (2018) ve Şahin (2015)'in bulgularıyla tutarlıyken Buğa (2009) ve Çaykuş (2020)'un bulgularıyla çelişmektedir. Araştırmamızda elde edilen bulgunun yaş gruplarının yakın olmasından etkilendiği düşünülebilir. Yetişkinliğe ulaşma algısının seçeneklerin niteliğini değerlendirme üzerinde anlamlı bir 
etkisinin bulunduğu yetişkinliğe ulaştıklarını düşünenlerin ortalamasının bazı yönlerden ulaşıp bazı yönlerden ulaşmadıklarını düşünenlere göre yüksek olduğu sonucuna ulaşılmıştır. Alanyazında bu değişkenin ilişkisinin daha önce incelenmediği görülmüştür. Geçmiş ilişki sayısının seçeneklerin niteliğini değerlendirme üzerinde anlamlı bir etkisinin olduğu, 2 ve üzeri ilişki yaşadığını belirten grubun ortalamasının 1 ilişki yaşadığını belirten gruptan daha yüksek olduğu sonucuna ulaşılmıştır. Bu bulgunun Şahin (2015)'in bulgusuyla çeliştiği görülmektedir. Araştırmada elde edilen bulgu seçeneklerin niteliğini değerlendirmenin tanımında yer alan geçmiş ilişkiler ve çevrede görülen ilişkilere göre mevcut ilişkinin değerlendirilmesi ifadesiyle örtüşmektedir. İlişki niteliğinin seçeneklerin niteliğini değerlendirme üzerinde anlamlı bir etkisinin bulunduğu, romantik ilişki ya da sevgili ilişkisi yaşadığını belirten grubun ortalamasının evli gruptan yüksek olduğu bulgusuna ulaşılmıştır. Bu bulgunun Şahin (2015)'in bulgusuyla çeliştiği Mamati (2018)'nin ve Büyükşahin (2006)'in bulgusuyla tutarlı olduğu görülmektedir. Bunun sebebi evli bireylerin ilişkiyi toplumsal normlara göre sürdürmeye odaklanması ve evlenmemiş bireylerin ideal ilişki içinde olup olmadıklarını sorgulamaları olabilir.

$\mathrm{Bu}$ çalışmada, cinsiyetin ilişki yatırımı üzerinde anlamlı bir etkisinin olduğu, erkeklerin kadınlardan daha yüksek yatırım düzeyine sahip oldukları sonucuna ulaşılmıstır. Bu bulgu Çelik-Zeren (2020)'in bulgusuyla tutarlıdır. Alanyazın incelendiğinde cinsiyetin anlamlı bir farklılık gösterdiği ancak araştırma bulgumuzun aksine kadınların erkeklerden daha yüksek yatırım düzeyine sahip olduklarına ilişkin bulguların çoğunlukta olduğu görülmektedir (Rusbult ve ark. 1998, Fitzpatrick ve Sollie 1999, O'Sullivan ve ark. 2006, Taluy 2013). Ayrıca cinsiyetin ilişki yatırımı üzerinde anlamlı bir etkisinin bulunmadığına dair çalışmalar da bulunmaktadır (Le ve Agnew 2003, Şahin 2015, Uzun 2017, Akarsu 2018, Aktaş-Akbayrak 2019, Çaykuş 2020). Araştırmamızda elde edilen bulgunun alanyazınla çeliştiği görülmektedir. Bu durum kültürel farklılıklardan kaynaklanıyor olabilir. Kültürel olarak erkekler daha özgür oldukları için ilişki içinde kendilerini daha fedakar olarak nitelendirmiş olabilirler. Yaşın ilişki yatırımı üzerinde anlamlı bir etkisinin bulunmadığı sonucuna ulaşılmıştır. Bu sonuç, Uzun (2017), Mamati (2018) ve Şahin (2015)'in bulgusuyla tutarlıyken, Çaykuş (2020)'un çalışmasındaki yetişkin bireylerin, beliren yetişkinlerden daha yüksek yatırım düzeyine sahip olduğu bulgusuyla çelişmektedir. Bu durum yatırımın nesnel ölçütlerle değerlendirilememesinden kaynaklanıyor olabilir. Yetişkinliğe ulaşma algısının ilişki yatırımı üzerinde anlamlı bir etkisinin bulunmadığı, alanyazın incelendiğinde bu değişkene ait bir çalışma olmadığı görülmüştür. Bu bulgunun araştırmamızın özgün bir bulgusu olduğu söylenebilir. Geçmiş ilişki sayısının ilişki yatırımı üzerinde anlamlı bir etkisinin olduğu, 1 ilişki yaşadığını belirten grubun ortalamasının 2 ve üzeri ilişki yaşadığını belirten gruptan yüksek olduğu bulunmuştur. Bu sonucun Şahin (2015)'in bulgusuyla çeliştiği görülmektedir. Bu bulgu tek ilişki yaşayan bireylerin ilişkinin sonlanmasıyla yaşayacakları kaybı daha yıkıcı değerlendirmelerinden kaynaklanıyor olabilir. İlişki niteliğinin ilişki yatırımı üzerinde anlamlı bir etkisinin olduğu, evli bireylerin ortalamasının romantik ilişki ya da sevgili ilişkisi yaşayan bireylerden daha yüksek olduğu bulunmuştur. Bu bulgu Mamati (2018)'nin medeni durumun yatırımı etkilemediği bulgusuyla çelişirken, Şahin (2015) ve Büyükşahin (2006)'in bulgusuyla tutarlıdır. Araştırmamızdaki bulgunun flört ilişkisinde iki ayrı birey olan partnerlerin evlilik bağıyla hayatlarının iç içe geçmesi gerektiği yönündeki kültürel algıdan etkilendiği söylenebilir. 
$\mathrm{Bu}$ çalışmada cinsiyetin bağlanım üzerinde anlamlı bir etkisinin bulunmadığı sonucuna ulaşılmıştır. Bu sonuç Çelik-Zeren (2020)'nin bulgusuyla tutarlıyken, Fitzpatrick ve Sollie (1999), Le ve Agnew (2003), Taluy (2013) ve Çaykuş (2020)'nin çalışmalarındaki kadınların, erkeklere göre daha fazla bağlanım geliştirdikleri bulgusuyla çeliştiği görülmektedir. Araştırmamızda elde edilen bulgunun alanyazınla çelişmesinin sebebi internet üzerinden gönderilen ölçekleri, eşlerin bir arada doldurmaları ve birbirlerini etkilemeleri olabilir. Yaşın bağlanım üzerinde anlamlı bir etkinin bulunduğu, 26-29 yaş grubunun ortalamasının 18-25 yaş grubuna göre daha yüksek olduğu sonucuna ulaşılmıştır. Bu sonuç Fitzpatrick ve Sollie (1999), Buğa (2009) ve Çaykuş (2020)'un bulgusuyla tutarlıdır. Yetişkinliğe ulaşma algısının bağlanım üzerinde anlamlı bir etkisinin bulunmadığı, alanyazında bu değişkenin çalışılmadığı görülmüştür. $\mathrm{Bu}$ bulgunun özgün olduğu söylenebilir. Geçmiş ilişki sayısının bağlanım üzerinde anlamlı bir etkisinin olduğu, 1 ilişki yaşayan grubun ortalamasının 2 ve üzeri ilişki yaşadığını belirten gruptan yüksek olduğu sonucuna ulaşılmıştır. Alanyazın incelendiğinde bağlanım alt ölçeğinin çok az araştırmada kullanıldığı ve bu demografik değişkenin daha önce çalışılmadığı görülmektedir. İlişki niteliğinin bağlanım üzerinde anlamlı bir etkinin bulunduğu, evli bireylerin ortalamasının romantik ilişki ya da sevgili ilişkisi yaşadığını belirten gruptan daha yüksek olduğu sonucuna ulaşılmıştır. Bu sonuç Mamati (2018)'nin bulgusuyla tutarlıdır. Bu durum evli bireylerin, romantik ilişki içinde olan bireylere göre mevcut ilişkilerini daha fazla sahiplenmelerinden kaynaklanıyor olabilir.

Araştırma grubunu oluşturan katılımcıların ilişki istikrarı, anneye bağlanma ve tamamlanma ihtiyacı değişkenleri arasındaki ilişkiler Path modeli analizi ile incelenmiştir. Buna göre Path analizi sonucuna bakıldığında hem anneye bağlanmanın hem de tamamlanma ihtiyacının ilişki istikrarının düşük düzeyde yordayıcıları olduğu bulgusuna ulaşılmıştır. Model analizinde anneye bağlanma ve bilişsel tamamlanma ihtiyacı, ilişki istikrarı ile düşük düzeyde pozitif ilişkili bulunmuştur.

Yapılan analiz sonucunda, bilişsel tamamlanma ihtiyacının anneye bağlanma ile ilişki istikrarı arasında aracıllk rolü gözlenmektedir. Anneye bağlanma tamamlanma ihtiyacına etki etmekte; bu durum ise ilişki istikrarına etki etmektedir. Bulgulara toplam etkiler başlı̆̆1 altında bakıldığındaysa anneye bağlanmanın ilişki istikrarı üzerinde düşük düzeyde pozitif bir etkisinin olduğu görülmektedir.

Türkiye'deki akademik çalışmalar incelendiğinde, bilişsel tamamlanmanın çocukluk çağı ruhsal travmalarıyla duygusal ve tıkınırcasına yeme (Dobur 2019), kompulsif alı̧veriş davranışı (Çarıkcı 2019), çevrimiçi oyun bağımlılığı (Deliktaş 2020) ve riskli davranı̧̧lar (Yazgan 2020) gibi çeşitli değişkenlerle ilişkili olduğunun belirlendiğgi çalışmalar bulunmasına karşın anneye bağlanma ve bilişsel tamamlanma ihtiyacı ilişkisinin incelendiği tek çalışmanın Aksu (2019) tarafından yapıldığı görülmektedir. Aksu (2019), 18-26 yaş arası bireylerle gerçekleştirdiği çalı̧̧masında anneye bağlanma ve bilişsel tamamlanma ihtiyacı arasında düşük düzeyde pozitif ilişki olduğu sonucuna ulaşmıştır. Bu sonuç çalışmamızda elde ettiğimiz bulguyu desteklemektedir.

Alanyazın incelendiğinde anneye bağlanma ve romantik ilişkilerin birlikte araştırıldığı çalışmalar bulunduğu görülmektedir. Bu çalı̧̧alardan birinde Akbay (2015) annelerini ilgili olarak algılayan bireylerin, yaşamlarının ilk on altı yılı düşünüldüğünde, romantik ilişki kurmaktan daha az kaçındıkları ve ilişkilerinde daha az kaygı yaşadıkları sonucuna ulaşmıştır. Akdağ (2017) genç yetişkinlerin, anne bağlanma örüntüsünün, romantik ilişkilerdeki bağlanmaya ilişkin kaçınma üzerinde anlamlı bir yordayıcı olduğu sonucuna ulaşmış ve Sığırcı (2010) ise kaçınmalı bağlanma stilinin evlilik doyumunu anlamlı 
düzeyde yordadığını tespit etmiştir. Ercan (2016) yaptığı araştırmasında anneye bağlanma düzeyi yüksek olan bireylerin, tutkulu aşk ve arkadaşça aşk ölçeklerinden yüksek puanlar aldığ1 sonucuna ulaşmıştır. Büyükşahin ve arkadaşları (2005) araştırmalarında, İÏÖ ve LAS alt ölçekleri arasındaki ilişkiyi ayrı ayrı ele aldıklarında, ilişki doyumu ile arkadaşça aşk, tutkulu aşk, özgeci aşk ve sahiplenici aşk alt ölçekleri arasında anlamlı ve pozitif bir ilişki bulmuşlardır. Bu aşk biçimlerinin genel özellikleri dikkate alınarak ilişki doyumu alt ölçeğiyle bağlantılı olduğu ileri sürülebilir. Büyükşahin ve arkadaşları (2005) ile Ercan (2016)'ın çalışmasının bulguları ilişkilendirildiğinde anneye bağlanma ve ilişki istikrarının alt ölçeklerinden olan ilişki doyumunun, iki çalışmada da aşk stilleri ortak paydasında anlamlı sonuçlar verdiği söylenebilir. Literatür incelendiğinde Türkiye'de anneye bağlanmanın, ilişki istikrarını anlamlı düzeyde yordayıp yordamadı̆̆ı ile ilgili çalışmaya rastlanmamıştır.

\section{Sonuç}

Araştırmanın temel amacı olan ve hipotez modelde bahsedilen anneye bağlanma ve ilişki istikrarı arasındaki ilişkide tamamlanma ihtiyacının aracılık rolünün incelenmesi sonucunda aracılık etkisinin olduğu bulgusuna ulaşılmıştır. Araştırma kapsamında formlar internet üzerinden belirli sayıda katılımcıya uygulanmıştır. Katılımcıların dikkatlerini toplamaları, formu bireysel olarak doldurup doldurmadıkları gibi birçok faktör gözlemlenememiştir. Gelecek çalışmaların daha çok katılımcıyla ve yüz yüze yapılması alana katkı sağlayabilir. Bu araştırma anneye bağlanma toplam puanları üzerinden yapılmıştır. Bunun sonucunda alt ölçek puanları ile ilgili bulgular incelenmemiştir. $\mathrm{Bu}$ araştırmaya benzer konularda çalışmak isteyen araştırmacıların anneye bağlanma alt ölçek puanlarından elde edilen bulguları incelemeleri alana katkı sağlayabilir. Ayrıca ilişki istikrarıyla ilgisi olduğu düşünülen ebeveyn bağlanma stilleri ve yetişkin bağlanma stilleri konularını çalışarak alana katkı sağlayabilecekleri düşünülmektedir. Bu bağlamda araştırmacıların yeni çalışmalar planlarken bu konuyu dikkate almaları önerilmektedir.

Beliren yetişkinlik eş, iş ve dünya görüşünün şekillendiği bir yaşam dönemidir. $\mathrm{Bu}$ dönemdeki bireylerin ruh sağlığı birimlerine başvurma sebeplerinin en başında romantik ilişkilerinde yaşadıkları sorunların geldiği görülmektedir. Romantik ilişkisi olan bireylerle yürütülen çift terapisi son zamanlarda öne çıkan bir danışma hizmeti olmuştur. $\mathrm{Bu}$ araştırmada ortaya koyulan bulgular ışığında alan çalışanlarına, anneye bağlanma ile ilişki istikrarı arasındaki ilişkiyi analiz etmeleri, önleme ve müdahale çalı̧̧malarını şekillendirirken bu bulgulardan faydalanmaları önerilmektedir. Bilişsel tamamlanma ihtiyacının ilişki istikrarı üzerinde anlamlı bir etkisinin olduğu bulgusunun, ilişki istikrarına bilişsel-davranışçı yaklaşımla müdahalede edecek olan psikolojik danışmanlar, diğer alan çalışanları ve uzmanların kullanımına fayda sağlayacağı düşünülmektedir. Bu bağlamda planlanacak önleme ve müdahale çalışmalarında alan çalışanlarına, bilişsel tamamlanma ihtiyacı faktörünü de değerlendirmeleri önerilmektedir. Türkiye'de anneye bağlanmanın bilişsel tamamlanma ihtiyacı ile ilişkisinin incelendiği bir çalışma bulunmasına karşın anneye bağlanma, bilişsel tamamlanma ihtiyacı ve ilişki istikrarı değişkenleri arasındaki ilişkiyi ortaya koyan bir çalışmanın bulunmadığı görülmektedir. Bu bağlamda ortaya koyulan araştırma sonuçlarının gelecekte yapılacak akademik çalışmalara katkı sağlayacağı düşünülebilir. 


\section{Kaynaklar}

Adams JM, Jones WH (1999) Interpersonal commitment in historical perspective. In Handbook of Interpersonal Commitment and Relationship Stability, 2nd ed. (Eds JM Adams, WH Jones):3-34. New York: Kluwer Academic/Plenum Press Publishers.

Agnew C (2009) Commitment, Theories and Typologies. West Lafayette, IN, Purdue University Department of Psychological Sciences Faculty Publications. Paper 28.

Ainsworth MDS (1969) Object relations, dependency, and attachment: A theoretical review of the infant-mother relationship. Child Dev, 40:969-1025.

Akarsu Ş (2018) Üniversite öğrencilerinin ilişki istikrarı ile sosyal ilgi, ilişkisel benlik saygısı ve maneviyatları arasındaki ilişki (Yüksek lisans tezi). Ankara, Gazi Üniversitesi.

Akbay SE (2015) Ana-babaya bağlanma ile romantik yakınlık ve otantik benlik arasındaki ilişkilerde bağlanma stillerinin aracı rolünün incelenmesi (Doktora tezi). Mersin, Mersin Üniversitesi.

Akdağ C (2017) Genç yetişkin bireylerin anne-babalarıyla kurdukları ilişki örüntüsünün romantik ilişkilerindeki kaygı ve kaçınma düzeylerini yordama gücü (Yüksek lisans tezi). İstanbul, Marmara Üniversitesi.

Aksu M (2019) Yetişkinliğe geçişte anne-babaya bağlanma ile problemli internet kullanımı ilişkisinde bilişsel tamamlanma ihtiyacının aracılık etkisi (Yüksek lisans tezi). Kırıkkale, Kırıkkale Üniversitesi.

Aktaş-Akbayrak S (2019) Evli bireylerin ilişki istikrarının algıladıkları eş desteği ve ilişki yükleme biçimleri ile ilişkisi (Yüksek lisans tezi). Eskişehir, Anadolu Üniversitesi.

Aral N, Baran G, Bulut Ş, Çimen S (2001) Çocuk Gelişimi 2. İstanbul: I Ya-Pa.

Armsden GG, Greenberg MT (1987) The Inventory of parent and peer attachment: ındividual differences and their relationship to psychological well-being in adolescence. J Youth Adolesc, 16:427-454.

Arnett JJ (2000) Emerging adulthood: A theory of development from the late teens through the twenties. Am Psychol, 55:469480.

Atak H (2010) Yetişkinliğe geçişte kimlik biçimlenmesi ve eylemlilik (agency): Bireyleşme sürecinde iki gelişimsel kaynak (Doktora tezi). Ankara, Ankara Üniversitesi.

Atak H, Taştan N (2012) Romantik ilişkiler ve aşk. Psikiyatride Güncel Yaklaşımlar, 4:520-546.

Atak H, Syed M, Çok F, Tonga Z (2016) Yeni bir nöropsikolojik kavram olarak tamamlanma intiyacı. Psikiyatride Güncel Yaklaşımlar, 8:290-299.

Avcı N (2003) Gelişimde 0-3 Yaş. Yaşama Merhaba. İstanbul, Morpa Kültür.

Buğa D (2009) Yakın ilişkilerde istikrar: bağlanma stilleri ve toplumsal cinsiyet rolleri açısından bir karşılaştırma (Yüksek lisans tezi). Ankara, Ankara Üniversitesi.

Büyükşahin-Sunal A, Hasta D, Hovardaoğlu S (2005) İlişki İstikrarı Ölçeği (iï)): Geçerlik ve güvenirlik çalışması. Türk Psikoloji Yazıları, 8:25-35.

Büyükşahin Ayda (2006) Yakın ilişkilerde bağlanım: yatıım modelinin bağlanma stilleri ve bazı ilişkisel değişkenler yönünden incelenmesi (Doktora tezi). Ankara, Ankara Üniversitesi.

Çarıkcı Ni (2019) Anne-babaya bağlanma, çocukluk çağı ruhsal travmaları ve tamamlanma ihtiyacının kompulsif alışveriş üzerindeki etkisi (Yüksek lisans tezi). Kırıkkale, Kırıkkale Üniversitesi.

Çaykuş ET (2020) İlişki istikrarı: ilişkilerde güç algısı, ilişkisel alçakgönüllülük ve romantik ilişkilerde obsesyon ve kompulsiyon ilişkilerinin incelenmesi (Doktora tezi). Eskişehir, Eskişehir Osmangazi Üniversitesi.

Çelik-Zeren D (2020) Üniversite öğrencilerinin ilişki istikrarı ile flörtte şiddete yönelik tutumları arasındaki ilişkinin incelenmesi (Yüksek lisans tezi). İstanbul, İstanbul Ticaret Üniversitesi.

Deliktaş 0 (2020) Ahlaki kimlik ve bilişsel tamamlanma ihtiyacının çevrimiçi oyun bağımlıı̆ı üzerindeki etkisi (Yüksek lisans tezi). Kırıkkale, Kırıkkale Üniversitesi.

Dobur HA (2019) Yetişkinliğe geçişte çocukluk çağı ruhsal travmaları ile duygusal yeme ve tıkınırcasına yeme ilişkisinde bilişsel tamamlanma ihtiyacının aracılık etkisi (Yüksek lisans tezi). Kırıkkale, Kırıkkale Üniversitesi.

Ercan H (2016) Üniversite öğrencilerinin aşk stillerinin demografik değişkenler ve ana babaya bağlanma ile ilişkisi. Adnan Menderes Üniversitesi Eğitim Fakültesi Eğitim Bilimleri Dergisi, 7:25-37. 
Eryılmaz A, Ercan L (2010) Beliren yetişkinlikte romantik yakınlığı başlatma ve başa çıkma. Uludağ Üniversitesi Eğitim Fakültesi Dergisi, 23:381-397.

Fehr B (2003) The status of theory and research on love and commitment. In Blackwell Handbook of Social Psychology: Interpersonal Processes, 2nd ed. (Eds GJ0 Fletcher, MS Clark):331-356. New Jersey, Blackwell Publishing.

Fitzpatrick J, Sollie DL (1999) Unrealistic gendered and relationship spesific beliefs: Contributions to investments and commitment in dating relationships. Pers Relatsh, 16:852-868.

Gómez-López M, Viejo C, Ortega-Ruiz R (2019) Psychological Well-Being during adolescence: Stability and association with romantic relationships. Front Psychol, 10:1772.

Goode WJ (1959) The theoretical importance of love. Am Sociol Rev, 24:38-47.

Günaydın G, Selçuk E, Sümer N, Uysal A (2005) Ebeveyn ve arkadaşlara bağlanma envanteri kısa formunun psikometrik açıdan değerlendirilmesi. Türk Psikoloji Yazıları, 8:13-23.

Hinde RA, Hinde RA (1979) Towards Understanding Relationships. London: Academic Press.

Işınsu-Halat M (2009) Yatııım kuramı bağlamında evli çiftlerde uyum, nedensel ve sorumluluk yüklemeleri ile yalnızlık arasındaki bağlantılar (Doktora tezi). Ankara, Ankara Üniversitesi.

Johnson MP (1991) Commitment to personal relationships. In Advances in Personal Relationships, 2nd ed. (Eds WH Jones, DW Perlman):117-143. London: Jessica Kingsley.

Kelley HH, Berscheid E, Christensen A, Harvey JH, Huston TL, Levinger G, Peterson DR (1983) Analyzing close relationships. In Close Relationships, 2nd ed. (Eds HH Kelley, E Berscheid, A Christensen, JH Harvey, TL Huston, G Levinger, DR Peterson):20-67. New York: Freeman.

Kruglanski AW, Webster DM (1996) Motivated closing of the mind: "seizing" and "freezing". Psychol Rev, 103:263-283.

Le B, Agnew CR (2003) Commitment and its theorized determinants: A meta-analysis of the Investment Model. Pers Relatsh, 10:37-57.

Levinger G (1965) Marital cohesiveness and dissolution: An integrative review. J Marriage Fam, 27:19-28.

Mamati G (2018) Heteroseksüel çift ilişkisi içindeki kadınlarda çocukluk çağı travmalarının ve semptomlarının ilişki istikrarı ile arasındaki ilişkinin incelenmesi (Yüksek lisans tezi). İstanbul, İstanbul Arel Üniversitesi.

Mannetti L, Pierro A, Kruglanski A, Taris T, Bezinovic P (2002) A cross - cultural study of the Need for Cognitive Closure Scale: Comparing its structure in Croatia, Italy, USA and The Netherlands. Br J Soc Psychol, 41:139-156.

Mayseless 0, Kruglanski AW (1987) What makes you so sure? Effects of epistemic motivations on judgmental confidence. Organ Behav Hum Decis Process, 39:162-183.

O'Sullivan LF, Hoffman S, Harrison A, Dolezal C (2006) Men, multiple sexual partners, and young adults' sexual relationships: understanding the role of gender in the study of risk. Bull N Y Acad Med, 83:695-708.

Prager KJ (1995) The Psychology of Intimacy: Guilford Series on Personal Relationships. New York: Guilford.

Raja SN, Mcgee R, Stanton WR (1992) Perceived attachments to parents and peers and psychological well-being in adolescence. J Youth Adolesc, 21:471-485.

Reis HT, Collins WA, Berscheid E (2000) The relationship context of human behavior and development. Psychol Bull, 126:844-872.

Roets A, Van Hiel A (2011) Item selection and validation of a brief, 15-item version of the Need for Closure Scale. Pers Individ Dif, 50:90-94.

Rusbult CE (1980) Commitment and satisfaction in romantic associations A test of the investment model. J Exp Soc Psychol, $16: 172-186$

Rusbult CE (1983) A longitudinal test of the investment model: The development (and deterioration) of satisfaction and commitment in heterosexual involvements. J Pers Soc Psychol, 45:101-117.

Rusbult CE, Coolsen MK, Kirchner JL, Clarke JA (2006) Commitment. In: The Cambridge Handbook of Personal Relationships, 2nd ed. (Eds AL Vangelisti, D Perlman):615-635. Cambridge, Cambridge University Press.

Rusbult CE, Martz JM, Agnew CR (1998) The investment model scale: Measuring commitment level, satisfaction level, quality of alternatives, and investment size. Pers Relatsh, 5:357-387.

Sacher JA, Fine MA (1996) Predicting relationship status and satisfaction after six months among dating couples. J Marriage Fam, 58:21-32. 
Sığırcı A (2010) Evli bireylerde bağlanma biçimleri ve evliliğe dair inançların evlilik doyumu ile ilişkisinin incelenmesi (Yüksek lisans tezi). Malatya, İnönü Üniversitesi.

Şahin C (2015) 20-40 yaş arası bireylerde erken dönem uyumsuz şemalar ve ilişki istikrarı arasındaki ilişkilerin incelenmesi (Yüksek lisans tezi). İstanbul, Haliç Üniversitesi.

Şimşek ÖF (2007) Yapısal Eşitlik Modellemesine Giriş - Temel IIlkeler ve Lısrel Uygulamaları. Ankara, Ekinoks.

Tai T, Baxter J, Hewitt B (2014) Do co-residence and intentions make a difference? Relationship satisfaction in married, cohabiting, and living apart together couples in four countries. Demogr Res. 31:71-104.

Taluy N (2013) İkili ilişkilerde mükemmeliyetçilik ve çatışma çözme tepkileri: yatırım modeli çerçevesinde yapılan bir çalışma (Doktora tezi). Ankara, Ankara Üniversitesi.

Thibaut JW, Kelley H (1959) The Social Psychology of Groups. New York: John Wiley \& Sons.

Uzun KN (2017) Bağlanma stilleri ile evlilikte ilişki istikrarı arasındaki ilişkinin incelenmesi (Yüksek lisans tezi). İstanbul, İstanbul Ticaret Üniversitesi.

Webster DM, Kruglanski AW (1994) Individual differences in need for cognitive closure. J Pers Soc Psychol, 67:1049-1062.

Webster DM, Kruglanski AW (1998) Cognitive and social consequences of the motivation for closure. Eur Rev Soc Psychol, 8:133146.

Yazgan G (2020) Üniversite öğrencilerinde riskli davranışlar: internet bağımlıı̆̆ı ve bilişsel tamamlanma ihtiyacının etkisi (Yüksek lisans tezi). Kırıkkale, Kırıkkale Üniversitesi.

Yazarların Katkıları: Yazarlar çalışmaya önemli bir bilimsel katkı sağladıklarını ve makalenin hazırlanmasında veya gözden geçirilmesinde yardımcı olduklarını kabul etmişlerdir.

Danışman Değerlendirmesi: Dış bağımsız

Etik Onay: Araştırma için Kırıkkale Üniversitesi Sosyal ve Beşerî Bilimler Araştırmaları Etik Kurulundan onay alınmıştır. Tüm katılımcılar aydınlatılmış onam vermişlerdir.

Çıkar Çatışması: Yazarlar çıkar çatışması bildirmemiştir.

Finansal Destek: Yazarlar bu çalışma için finansal destek almadıklarını beyan etmişlerdir.

Authors Contributions. Authors attest that they have made an important scientific contribution to the study and have assisted with the drafting or revising of the manuscript.

Peer-review: Externally peer-reviewed.

Ethical Approval: Ethical approval was obtained from Kırıkale University Social and Human Sciences Studies Ethics Committee for the study. All participants gave informed consent.

Conflict of Interest: No conflict of interest was declared by the authors.

Financial Disclosure: The authors declared that this study has received no financial support. 